\title{
Immune-cancer interactions in tumors and tumor-draining lymph nodes: Novel prognostic indicators for breast cancer
}

\author{
James Mansfield ${ }^{1 *}$, Peter Lee $^{2}$ \\ From Society for Immunotherapy of Cancer 29th Annual Meeting \\ National Harbor, MD, USA. 6-9 November 2014
}

It is becoming clear that immune cells play many important but sometimes conflicting roles in cancer. Immune profile changes at sites of immune-cancer interactions, such as the tumor microenvironment and tumor-draining lymph nodes (TDLNs), may represent a sensitive predictor of local and distant tumor metastasis. However, standard pathologic analysis of tumor sections has remained at the visual assessment of one marker per serial section level; it would be extremely useful to be able to visualize the distributions of multiple phenotyped immune and other cells in-situ in solid tumors to dissect the complex interplay between immune/stromal cells and cancer cells within tumors, tumor-draining lymph nodes (TDLNs), and blood. We generate immune profiles that include complete immunophenotyping and identification of cellular spatial relationships within and between the tumor microenvironment and TDLNs from formalin-fixed paraffin-embedded lymph node and tumor specimens from cancer patients using a combination of multiplexed IHC/IF, multispectral imaging, and automated image analysis which delivers quantitative per-cell measures of each marker. These percell intensities are then translated into a phenotype for each cell. We have found that immune cell populations as well as their spatial distributions and clustering patterns have strong correlation with clinical outcome.

\section{Authors' details}

'PerkinElmer, Hopkinton, MA, USA. ${ }^{2}$ City of Hope Comprehensive Cancer Center, CA, USA.
Published: 6 November 2014

\section{doi:10.1186/2051-1426-2-S3-P255}

Cite this article as: Mansfield and Lee: Immune-cancer interactions in tumors and tumor-draining lymph nodes: Novel prognostic indicators for breast cancer. Journal for ImmunoTherapy of Cancer 2014 2(Suppl 3): P255.

'PerkinElmer, Hopkinton, MA, USA

Full list of author information is available at the end of the article

Submit your next manuscript to BioMed Central and take full advantage of:

- Convenient online submission

- Thorough peer review

- No space constraints or color figure charges

- Immediate publication on acceptance

- Inclusion in PubMed, CAS, Scopus and Google Scholar

- Research which is freely available for redistribution
() Biomed Central 